\title{
Fighting Organized Crime in Mexico: 2006-2012
}

\author{
Gerardo Reyes Guzmán ${ }^{1}$, Ignacio Ibarra López ${ }^{2}$, Ariel Alcantara Eguren ${ }^{3}$ \\ ${ }^{1}$ Centro de Estudios de Desarrollo Regional, Colegio de Tlaxcala, Tlaxcala, Mexico \\ ${ }^{2}$ Centro de Estudios Políticosy Sociales, Colegio de Tlaxcala, Tlaxcala, Mexico \\ ${ }^{3}$ Departamento de Ciencias de la Salud, Universidad Iberoamericana Puebla, Puebla, Mexico
}

Email address:

gerardo1960@yahoo.com (G. R. Guzmán), Ignacio_ibarra@msn.com (I. I. López), ecogeos@yahoo.com.mx (A. A. Eguren)

\section{To cite this article:}

Gerardo Reyes Guzmán, Ignacio Ibarra López, Ariel Alcantara Eguren. Fighting Organized Crime in Mexico: 2006-2012. International Journal of Economics, Finance and Management Sciences. Vol. 3, No. 5, 2015, pp. 473-482. doi: 10.11648/j.ijefm.20150305.19

\begin{abstract}
According to the former president Felipe Calderon, the National Security Strategy, designed to overcome violence related with organized crime, made progress by the end of his Administration and improved security as a whole. This article sets two hypothesis based on Calderon's statement: the more money invested in security, the lower the rate of homicides and the higher the rate of homicides the lower Economic prosperity. We proved these hypotheses by comparing the rate of homicides during President Calderon with those computed by former president Ernesto Zedillo and Vicente Fox. Our finding show that President Calderon invested in security a lot more than his predecessors, but could not reduce the rate of homicides. At the end of his presidency, the country became more violent but more prosperous as well.
\end{abstract}

Keywords: Federal Expenditure Budget, Security, Homicides, GDP per Head

\section{Introduction}

The problem of violence in Mexico between 2006 and 2012, has been already addressed by several authors (Astorga, 2012; Paoli, 2010; Buscaglia, 2013; Dillsk, et al, 2008; Scherer, 2012, Ravelo, Coss, 2011, 2012; Reveles, 2012, Villalobos, 2012 ). For instance, Alejandro Poire, Calderon's former Interior Secretary, pointed out that violence in Mexico was concentrated in 73 municipalities, being the North the most dangerous region. Poiré assured the National Press that the Government Program to fight insecurity was making progress because homicides were subsiding. The number of homicides as a whole spiked from 2007 on, reaching its highest peak in November 2008. Homicides in Mexico ranked as the tenth cause of death in 2006 but they jumped to the seventh place in 2012. That was the result of severe clashes among drug cartels, disputing geographical zones of influence. These confrontations took place mainly in the northern part of the country. Poire stated that by the end of 2010, the trend of homicides started to fall. From 2006 to 2010, 50\% of homicides occurred in three Mexican Federal States: Chihuahua (29\%), Sinaloa (13\%) and Guerrero (8\%). By 2010, 70\% of the homicides occurred in 7 Federal Mexican States: Chihuahua (29\%); Sinaloa (12\%); Tamaulipas (8\%); Guerrero (7\%); Durango (7\%); Mexico (4\%) and Nuevo León (4\%).
The former President Felipe Calderon Hinojosa published a book in 2014 in which he explains the tenets and goals of his National Security Strategy (NSS). He recognizes that the NSS was not finished, but it had managed to turn down the high levels of insecurity prevailing when he took office in 2006. By the end of his administration, organized crime was losing grip, as his Government became even stronger (Calderon, 2014: 72).

We can derive two hypothesis from Calderon's statement. He believed that by reinforcing public forces through more money, insecurity - in terms of homicides- would subside. Organized crime was not only causing violence, but it was also obstructing economic progress by deteriorating business climate. Thus, the following questions arise: what was the cost of his NSS in terms of public expenditure? How efficient was the NSS in terms of homicides reduction? and how did violence affect the economic progress in terms of GDP per head? To prove the hypotheses and answer these questions, we divided the present paper into three sections. The first part summarizes the tenets of Calderon's NSS, focusing on those Federal States in which violence high rocketed. The second section analyses the Federal Budget Expenditures (FBE) to estimate the costs of the NSS in the public finances in relative and absolute terms. In this part, we make emphasis in the performance of the Security Ministry (Secretaria de Seguridad Pública). In the third section, we will correlate 
security expenditure vs homicides to prove if more resources available for public security managed to sink the rate homicides. We also prove here whether violence deteriorated the levels of wealth in terms of GDP per head. We compare three Presidential Administrations in Mexico: Ernesto Zedillo Ponce de León (EZP) 1994-2000; Vicente Fox Quezada (VFQ) 2000-2006 and Felipe Calderon Hinojosa (FCH) 2006-2012. At the end, we summarize the most important findings and draw some conclusions.

\section{National Security Strategy (NSS)}

Felipe Calderón published a book in 2014 in which he presents the NSS as one of the key policies of his Government. The NSS aimed at providing Mexican families with that security status taken away by organized crime. It pursue to reestablish law and order by fighting impunity and rebuilding social network. Calderón never declared war against organized crime, nor began a crusade against drug consumption or drug trafficking. On the contrary, he made several drugs legal for nonprofit purposes.

According to Calderon, organized crime evolves from a first stage by which it focuses on illicit trade - like smuggling, prostitution, human trafficking, trafficking of migrants, sale of prohibited substances, stolen merchandise, piracy, gambling, etc.- into a second stage, by which organized crime sieges the community and makes profit out of extortion, kidnapping, etc. The mob reaps big gains out of intimidation and pursues to monopolize legal trade through violence and eradication of all sorts of competition. Extortion starts by victimizing all those economic agents that move outside the law. They are the most vulnerable since their businesses are illegal and therefore they cannot resort justice so settle disputes. Calderon points out that when the rule of law prevails, those who break the law are brought to justice, but when that doesn't happen, normal citizens are helpless and the government fails to provide safety. Six factors can explain the outbreak of violence in Mexico (Calderon, 2014:30):

a) The neighborhood with the USA. Because the Caribbean route to transport drugs from South America to the USA derailed through security forces, the Mexican-American border emerged as a surrogate to smuggle drugs into the US.

b) The transition from drug trafficking into small-scale drug dealing, (Mexico evolved from being a net exporter to become a consumer). This has to do with the increase of income per head in Mexico and the advent of a profitable internal market for drugs. For instance, the consumption of cocaine among youngsters between 12 and 17 years old in Mexico augmented from $0.2 \%$ in 2002 to $0.4 \%$ in 2008 and it remained so until 2011. Marihuana went from $0.5 \%$ in 2002 to $1.2 \%$ in 2008 and $1.3 \%$ in 2011, whereas the usage of other drugs rose from $0.8 \%$ to $1.7 \%$ and back to $1.6 \%$ during the same period. Calderon explains that drug trafficking and drug dealing are two different businesses. Drug trafficking consist on setting up the logistics and transportation to place illegal substances in the US market; while drug dealing seeks to expand influence zones and expel competitors through violence.

c) The clashes among drug cartels. This has to do with Mexico becoming a drug consuming country and with different criminal groups becoming suppliers. They start in a small neighborhood and growth steadily until they reign up on a region within or through Federal states. Whereas drug traffickers use routes from south to north and rarely encounter with each other, drug dealers necessarily collide with each other, creating a state of conflict and violence.

d) Corruption. Eventually authorities have to deal with the problem, but they step back after thugs bribe them or intimidate them. The increasing number of murders in Mexico is a consequence of territorial disputes. This became evident as the Cartel del Pacífico and the Cartel de Juarez split in 2004. In this year, the Cartel del Pacifico started a war against the Zetas. Homicides rose vigorously in the Federal States of Chihuahua, Durango and Sinaloa.

e) The availability of US automatic weapons. Calderon attributes the spike of homicides after 2004 in Mexico to the derogation of a US law that prohibited the trade of assault weapons in 2004. After that, it became easy to purchase automatic weapons in the US market. The government found that $85 \%$ of the 160,000 weapons confiscated between 2006 a 2012, were acquired in the USA. In 2011, there were 8,000 gun shops located near the Mexican-American border. It is proven that the availability of weapons in a community, -either because of warfare, guerrilla or civil war- stirs up homicides and remains so for a while once the conflict has concluded.

f) Demography. As small-size drug businesses started to grow, the recruiting process expanded. That took place simultaneously with the urbanization. Increasing population demanded public services, including security. In the midst of the XX Century, 26 million Mexicans lived in urban areas; in 2010, there were already 77.5 million people living in cities. It emerged a growing deficit of employment, entertainment and education. Organized crime lured young people looking for job opportunities, while Calderon's government failed to provide enough employment. There is an inverse relationship between economic growth and the rate of crime in Mexico. For instance, by a GDP contraction of $-7.5 \%$ in 1994 , robbery rate spiked by $56.4 \%$.

Calderon recalls a particular case of violence in the US during the 90's. At that time, the rate of homicides suddenly plunged, thanks to the strengthening of security forces, mainly through a large number of police officers working in the streets. Calderón implemented the same model in Ciudad Juarez, Tijuana and Monterrey, but not in Guerrero, Tamaulipas and Durango. The NSS had three main objectives: a) to bring criminals to justice b) to strength and clean policy departments and c) to rebuild the social network. 
a) The government conducted Special operations when local authorities requested it; this intervention aimed at bringing back law and order, and had a temporally character. The federal government sent its elite unites of the Mexican Army, Navy and Federal Police. There were exceptions like in the case of Chihuahua, Tamaulipas and Veracruz, where the Federal forces took control of the whole security issues. The main task was to dislodge illegal trade operations including drugs, weapons and corruption among local authorities. Furthermore, the law against money laundry impaired banking operations among criminal groups. Progress was achieved in several areas: leaders of organized crime were incarcerated ( 24 out of the 37 most wanted criminals in 2009 were in jail in 2012 and 540 were extradited to the USA) and drug shipments as well as drug precursors were seized; vehicles, weapons and money were confiscated. In these operations, the Navy was a key factor. For instance, in Mexico City, federal authorities seized 205 million USD cash; confiscated 23 tons of cocaine in the port of Manzanillo and snatched 314 small, 113 light weapons, a rocket launcher and 287 hand grenades in Reynosa and Tamaulipas. Authorities seized such an amount of drugs including cocaine, heroin and marihuana, that it would have been possible to supply every young Mexican between 12 and 25 years old with more than 2,000 doses with it. Criminality diminished in those states where local authorities cooperated with Federal Security Forces and by which new members were hired. That was the case of Baja California up 2008 as well as Chihuahua and Nuevo León up 2010. In other states, only short term progress could be achieved, because once the Federal forces withdrew, criminality rebounded. That was the case of Guerrero, Tamaulipas and Michoacán. Calderón emphasized that unless Security forces are reshaped, criminality will continue thriving because it is well known that criminals operate under the protection of long existing justice structure.

b) Calderón initiated his NSS with a new Federal Police. A new bill entitled the Security forces to carry on investigations to preempt criminal acts. By the time Calderon started his Administration, there was 6,000 members of the police with bad reputation. The former Federal Agency of Investigation (AFI) was removed and a brand new Public Security staff was set and equipped with the most modern Technological tools, software and facilities (Sistema Único de Información Criminal). By the end of 2012, 7,000 out of the new 36,000 members of the police were College graduated. The new Public Security also hired professionals and scientists: engineers, detectives, psychologists, biologists, expert services, programmers, lawyers, computer experts, etc. The new police force introduced a brand new system of criminal data to trace suspects and lawbreakers. By the end of 2012, this unit had stored more than 500 million data. Mexican Security
Forces were - in terms of technology and facilities - at the level of the best in its kind worldwide. At the same time, the NSS launched a policy to fight kidnappings. Thank to this program, the people who set the Casino Royal - located in Monterrey 2011- in fire were spotted and captured. The Federal Government handed governors of conflict regions 67 bn MXN to modernize their local Public Security forces. The Mexican Army acquired planes, armoured vehicles, vessels, logistics, etc $^{1}$. Members of the Mexican Army got better salary, mortgages, and scholarships for their children, as well as insurance for the families of those fallen in combat.

c) Criminality evolves in three stages: predatory, parasitic and symbiotic. In the first stage, gangs operate but they are not able to subdue local authorities; in the second one, criminals can bribe officials and mingle in politics and in the third one, criminals acquire so much power that they already occupy positions in government and make political decisions. Such stage unfolded in the state of Michoacán. Criminal groups had expanded throughout the territory before Calderon took office. In spite of the efforts to eradicate crime, made by his predecessor Vicente Fox, criminality did not subside. In 2003, criminal groups were operating in 50 municipalities; three years later, they had already expanded in 276 municipalities. Criminals had managed to corrupt local authorities including police, judges and governors. Lack of opportunities in the labor market for youngsters combined with situations of poverty and marginality seemed to be fostering criminality. Thus, the government set networks composed by citizens to detect and denounce criminal activities and delinquents. Furthermore, several programs were implemented to strengthen communities; among the most famous ones was Limpiemos México and Todos Somos Juárez. The government invested 5 bn MXN in Todos Somos Juárez; $74 \%$ of the money was designated to support different projects including medical care, education, sports, and social development. Furthermore, Todos Somos Juárez supported the jobless, offered scholarships, financed facilities for education, sport and recreation, and it enrolled 21,808 families in Oportunidades, a public program to help the rather poor. This program managed to sink the number of homicides in Chihuahua by $90 \%$ from 2010 to 2012. The Federal Government implemented Todos Somos Juárez in Chihuahua and its municipalities. It turned out to be very successful. Public spending for crime prevention in Federal States and municipalities increased twice from 2010 to 2012, favoring the States of Chihuahua, Guerrero, Michoacán,

1 The Mexican Army acquired a G36, a German machine gun from Heckler \& Koch for several millions euros. However, since German government prohibits the sell of guns to countries who violet human rights, Hecker \& Koch provided the Mexican Army with know-how, means of productions and inputs, so that Mexico could produce its own machine guns. In 2006, the Mexican Army proudly presented a FX05 machine gun as its own. However, it is a version of the original G36. (Die Zeit, 18 Juni, 2015: 22). 
Nuevo León, Tamaulipas and Veracruz.

\section{Federal Expenditure in Security VS Homicides}

Five key areas computed its largest annual rate of growth between 2006 and 2012 in the Mexican Federal Expenditure Budget: 1. Provisions for salaries and fringe benefits (589\%); 2. Interior Ministry: (500\%); 3. Security: (437\%); 4. Tourism: $(410 \%)$ and 5. Social Development: (319\%). Interior Ministry as well as Security were directly related with $\mathrm{Mr}$. Calderon's NSS.

Table 1 shows the share of security areas in the Federal Budget Expenditure (FBE) in 2000, 2006 and 2012. We must realize that from 2000 to 2006, Vicente Fox Quezada (VFQ) run the country and Mr. Calderon was his successor being in office from 2006 to 2012. The last two columns in the right indicate the percentage change in the given periods. In time of VFQ from 2000 to 2006, total Security Expenditure increased by $26.34 \%$. The main areas of the Security, measured by its rate of growth, were the Judicial Power (151\%); followed by General Attorney (69.96\%) and Police $(40 \%)$ in the third place. However, we can also see that Security Expenditure (SE), diminished by $-25.8 \%$ and $-27.6 \%$ as a share of the FBE and GDP respectively. Conversely, during the Presidency of Felipe Calderón Hinojosa (FCH), Security Expenditure increase by $98 \%$. The most favored areas were Interior Ministry and Police by $313 \%$ and $261 \%$ each. The Navy and Army increased as well by almost $77 \%$ percentage respectively. Thus, if SE as a share of the Federal Expenditure Budget dropped by $-25.8 \%$ from 2000 to 2006, it rebounded vigorously by $56.8 \%$ with $\mathrm{FCH}$.

Table 1. Security Expenditure as a share of the Federal Expenditure Budget (USD).

\begin{tabular}{|c|c|c|c|c|c|}
\hline & 2000 & 2006 & 2012 & $2000-2006(\%)$ & 2006-2012 (\%) \\
\hline GDP (trn USD) & 0.57 & 0.95 & 1.17 & 65.60 & 23.74 \\
\hline Federal Budget Expenditure (FBE) (bn USD) & 96.98 & 165.28 & 209.2 & 70.43 & 26.58 \\
\hline Total Security Expenditure (SE) (bn USD) & 5.95 & 7.52 & 14.95 & 26.34 & 98.56 \\
\hline Interior Ministry & 0.98 & 0.43 & 1.79 & -56.10 & 313.30 \\
\hline Army & 2.15 & 2.38 & 4.22 & 10.70 & 76.91 \\
\hline Public Security (Police) & 0.60 & 0.85 & 3.07 & 40.64 & 261.96 \\
\hline Navy & 0.84 & 0.83 & 1.49 & -0.27 & 77.85 \\
\hline General Attorney & 0.51 & 0.87 & 1.13 & 69.96 & 29.24 \\
\hline Judicial Power & 0.85 & 2.14 & 3.23 & 151.26 & 50.77 \\
\hline $\mathrm{SE}$ as a share of FBE (\%) & 6.15 & 4.56 & 7.15 & -25.87 & 56.86 \\
\hline FBE as a share of GDP $(\%)$ & 16.88 & 15.06 & 17.77 & -10.80 & 18.02 \\
\hline SE as a share of GDP (\%) & 1.09 & 0.79 & 1.27 & -27.69 & 60.46 \\
\hline
\end{tabular}

Source: PEF (Secretaría de Hacienda y Credito Público, 2012).

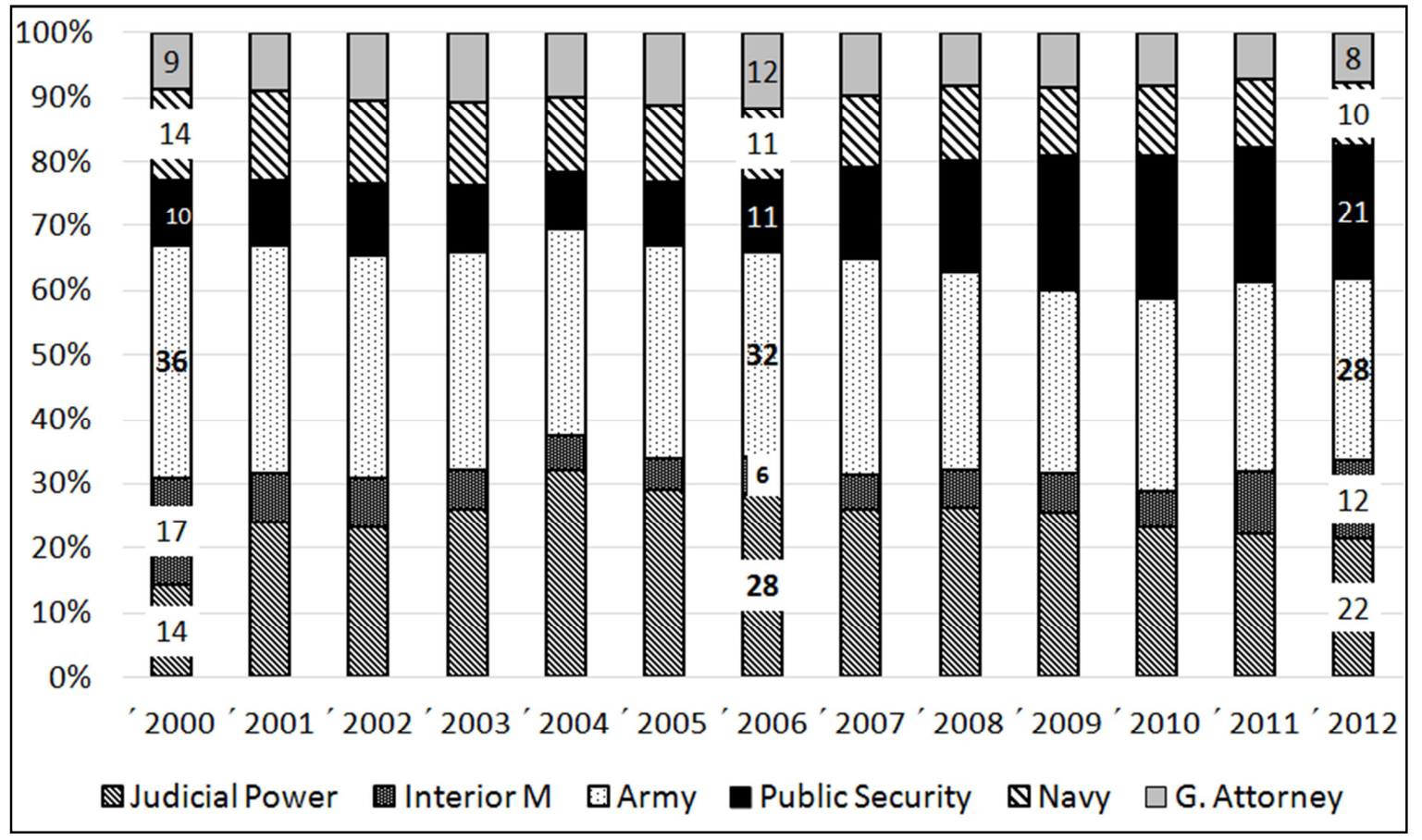

Source: PFE 
Graph 1 represents the distribution of SE from 2000 to 2012. By VFQ (2000-2006) only Judicial Power and General Attorney increased from $14 \%$ and $9 \%$ in 2000 to $28 \%$ and $12 \%$ respectively; whereas the rest of the SE components sank. Conversely, by FCH Judicial Power, Army, Navy and General Attorney dropped from 28\%, 32\%, $11 \%$ and $12 \%$ in 2006 to $22 \%, 28 \%, 10 \%$ and $8 \%$ in 2012 . The most favored components of SE in relative terms were again the Interior Ministry and Public Security. Both increased from $6 \%$ and $11 \%$ each in 2006 to $12 \%$ and $21 \%$ each in 2012 respectively. By the end of FCH's Administration, these two components absorbed more than one third of the SE. Since Public Security was in charge of the penitentiary system, we can mention that the numbers of prisoners increased from 210,140 in 2006 to 242,754 in 2012, while the number of jails shrank from 454 to 420 during the same time span. The construction of new jails could not keep pace with the increasing number of prisoners in spite of the whopping budget for security. Bergman y Azola, (2007: 81) point out that the poor infrastructure and the lack of trained personnel led to a high rate of impunity. Police jailed poor people for minor crimes. Furthermore, along the Calderon Administration, hundreds of convicts fled from Federal jails, due to the high levels of corruption and two Directors of the Interior Ministry died under dubious circumstances (Camilo Muriño in 2008 and Francisco Blake Mora in 2011).

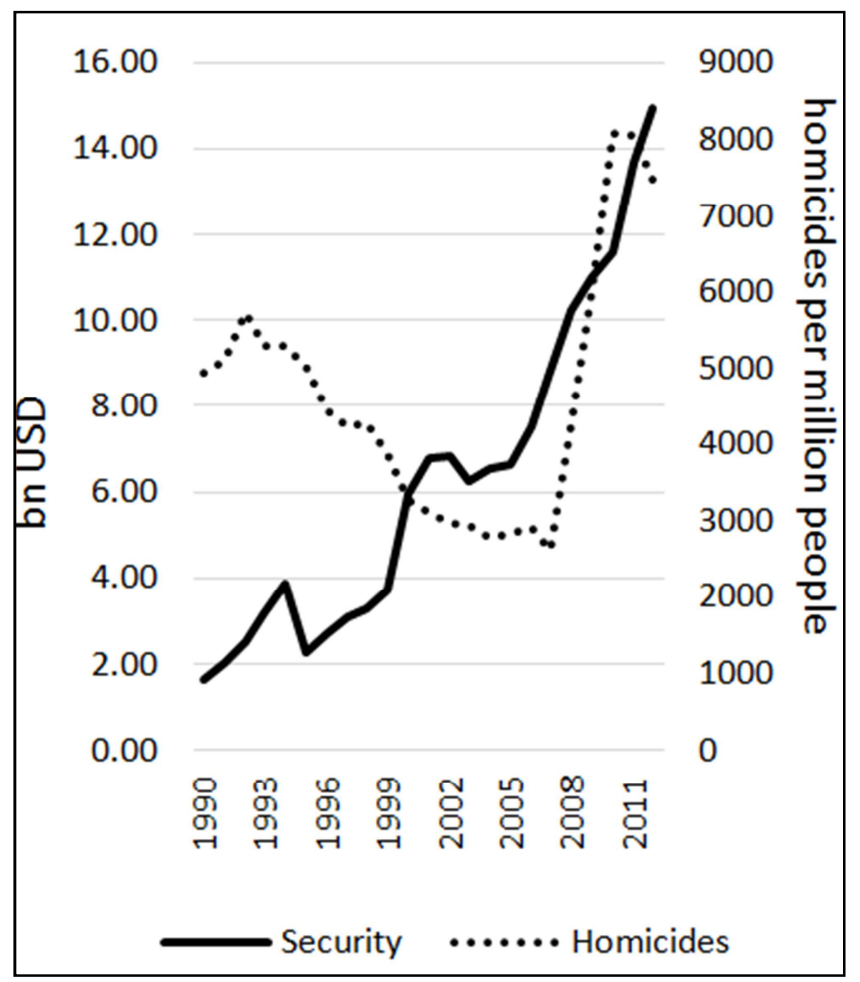

Source: Author's elaboration based on SSP and SHCP data.

Graph 2. Security Expenditure and Homicides.

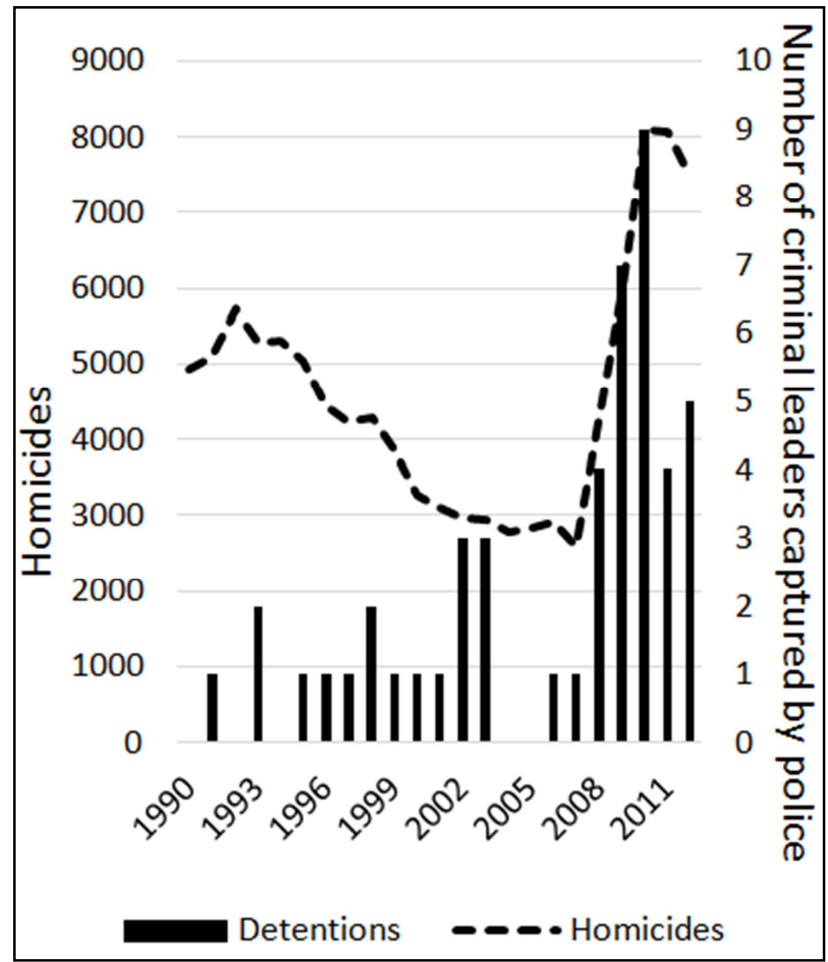

Source: Author's elaboration based on SSP and SHCP data.

Graph 3. Detention of Criminal leader vs Homicides.

\section{Public Expenditure, Homicides and Wealth}

As we can see from graph 2, SE had been growing permanently. On the other hand, homicides per million people reached a peak of 5280 in 1993 and began to sink reaching its lowest level in 2007 with 2605 homicides per million people. From that year on, they rebounded until they reached a record of 8092 homicides per million in 2010. This means that, as SE increased, so did the number of homicides. Graph 3 shows the relationship between criminal leaders captured by the authorities and the number of homicides. Before 2007, homicides were diminishing and the number of criminal leaders detained by the police was no more than three per year. After 2007, the number of jailed leaders augmented, but so did the number of homicides.

Being aware that the number of observations is rather small, we want to determine the influence of SE and detentions (DE) in homicides by using the following multiple correlation model:

$$
\mathrm{Y}=\beta_{0}+\beta_{1} \mathrm{X}_{1}+\beta_{2} \mathrm{X}_{2}+\varepsilon
$$

Where $Y$ is the dependent variable representing homicides; $\beta_{0}$ stands for the intercept, $\beta_{I}$ is the first independent variable and stands for the Security Expenditure (SE) and $\beta_{2}$ is the second independent variable and represents the number of criminal leaders captured by Federal forces (DE). The model was applied in three different intervals: 1990-1999; 20002005 and 2006-20012. The results can be seen in table 2: 
Table 2. Homicides, Expenditure and Criminal leader detentions.

\begin{tabular}{lll}
\hline Period & Model & Rsq \\
\hline $1990-1999$ & Homicides $=5614-0.0001957(\mathrm{SE})-272.16(\mathrm{DE})$ & 0.22 \\
$2000-2005$ & Homicides $=4481.50-0.0002364(\mathrm{SE})+29.71(\mathrm{DE})$ & 0.24 \\
$2006-2012$ & Homicides $=-2523.46+0.0005881(\mathrm{SE})+364.09(\mathrm{DE})$ & 0.90 \\
\hline
\end{tabular}

Source: Calculation on SSP data and local Press.

From 1990 to 1999 there was a negative relationship between Security Expenditure and homicides. Thus, for every 10,000 USD spent in security, homicides dropped by -1.9 and for every criminal captured by authorities, homicides diminished by 272.16 . However, since R-sq is only $22 \%$, this conclusion is still very weak. During the Administration of Vicente Fox, for every 10,000 USD spent in security, homicides shrank by -2.3 and for every criminal brought to justice by police forces, homicides increased by 29.71. This conclusion is also weak, since R-sq is $24 \%$. Conversely, as $\mathrm{Mr}$ Calderon was in office and implemented his NSS, for every 10,000 USD spent in SE, homicides increased by 5.8 and for every criminal leader put in jail, homicides increased by 364 . This time R-sq is $90 \%$, which is very strong and significant. That means, that his NSS based on financing military and police as well as the incarceration of mob leaders led to more homicides and therefore to more insecurity.

Now let's look at the territory as whole in three historical moments to see how insecurity evolved in Mexico. Map ${ }^{2} 1$ shows the evolution of violence in three Presidential periods: Ernesto Zedillo Ponce de León (EZP): 1994-2000, Vicente Fox Quezada (VFQ): 2000-2006 and Felipe Calderon Hinojosa (FCH): 2006-2012. As we can see there are five average ranking levels of violence per year, each represents the average annual rate of homicides per million people using a black white color graduation: high (black): 1000-2000; light black: 400-1000; grey: 200-400; light grey: 100-200 and white: 40-100. By EZP, violence focuses in the North Region at light black levels being the states of Chihuahua, Sinaloa and Baja California Norte the most violent. With an akin level scores the Southern region, by which Michoacán, Guerrero and Oaxaca come up as the most violent. Coahuila, Zacatecas, Aguascalientes, Guanajuato, Querétaro, Veracruz, Hidalgo, Nuevo León, Tabasco, Yucatán and Quitana Roo were peaceful states. Durango, Tamaulipas, San Luis Potosí, Puebla, State of Mexico, Morelos, Jalisco, Nayarit, Colima, Campeche and Chiapas appear in grey color. Secondly, by VFQ the country became more peaceful. The states that showed a light black color in the first period are now grey, except for Guerrero, which remains light black. Jalisco and Colima, Chiapas, Chetumal, Tamaulipas and San Luis Potosí turn white; that means, more peaceful. Finally, by FCH, violence spreads all over the country. Chihuahua turned high black, followed by Durango and Sinaloa, forming what is known as the Golden Triangle of drug trafficking. Nuevo León and Tamaulipas turned light black and Guerrero turned

2 To see the names of the 32 Mexican Federal States, please see the Map 3 at the Appendix. high black as well. The only states in white (peaceful), are: Aguascalientes, Guanajuato, Querétaro, México City, Puebla, Veracruz, Tabasco, Chiapas, Campeche and Yucatan.

Map 2 shows changes in GDP per head during the same periods. This time, the darker the color, the higher the level of wealth in terms of GDP per head. The richest entities by Zedillo are located in the North; they are Baja California Norte, Baja California Sur, Chihuahua, Coahuila and Nuevo Leon. Campeche and Quintana Roo, hosting oil industry and tourism respectively, jump as the wealthiest states in the South. During the presidency of VFQ, we observe an increase in the GDP per head in the country. The wealthy North expands and becomes more prosperous, including now the states of Sonora, Durango and Tamaulipas. Nuevo León emerges as the wealthiest of them. In the South Campeche and Quitana Roo remained as wealthy states, but this time Yucatan shows an increase of GDP per head as well. This betterment includes also the states of the center: Jalisco, Durango, Colima, Querétaro and Mexico City. By VFQ, Nuevo Leon and Campeche turned to be the richest states in Mexico. This has to do with a strong development of manufacturing and oil industry respectively. Finally, by $\mathrm{FCH}$, the whole country gets better, except for three states: Guerrero, Oaxaca and Chiapas. The wealthiest state was Campeche followed by Nuevo León and Querétaro. This was already a characteristic of the former period and can be explained by the high oil prices and a relative stable economic growth, except for the 2009 Economic downturn, which was a worldwide phenomenon.

Once we saw the evolution of homicides and GDP along the three periods, we pose two hypotheses: the high rate of homicides deteriorates business conditions leading to less productivity and hence to a lower GDP per head. The second hypothesis poses the opposite statement: The reduction in the levels of wealth in terms of GDP per head leads to more violence. To prove these hypotheses we will use the following econometric models:

$$
\begin{gathered}
\ln (G D P)_{i t}=\beta_{0}+\beta_{1} \ln (\text { Homicides })_{i t}+\gamma Z+e_{i t} \\
\ln (\text { Homicides })_{i t}=\alpha_{0}+\alpha_{1} \ln (G D P)_{i t}+\phi Z+u_{i t} \\
i=\{1,2, \ldots, 31\} ; k=\{1999,2000, \ldots, 2012\}
\end{gathered}
$$

Where $(G D P)_{i t}$ is the logarithm of GDP per head in the federal state $i$ for the year $t$. $\ln$ (Homicides) (Ht $_{i}$ is the logarithm of the number of homicides per million $i$ for the year $t$. The results of the first and second hypothesis can be read in tables $\mathrm{A} 1$ and $\mathrm{A} 2$ at the Appendix.

Table A1 shows that during the President EZP we find a significant correlation, so that for every percentage point of increase in homicides, GDP per head drops by -0.751 . The respective R-sq is 0.879, which is high among 192 observations. By VFQ, for every percentage point of increase in homicides, GDP per head drops by -0.083 . This is less than the former period but still significant. The respective R-sq is 0.952, which is high in 192 observations. By FCH for every 
percentage of increase in homicides, GDP per head increases by 0.025 and it is not significant.

Table A2 states that during the presidency of EZP for every percentage of increase in GDP, homicides dropped by -0.579 . The respective R-sq is 0.946 in 192 observations. This is very significant. By VFQ, for every increase in GDP, homicides dropped by -0.325 which is less but still significant in comparison with the former period. The respective R-sq is 0.914 in 192 observations. By $\mathrm{FCH}$, for every percentage point of increase in GDP, homicides increase by 0.475 . In this case, the correlation is not significant and the R-sq explains only $69 \%$ of the cases in 192 .

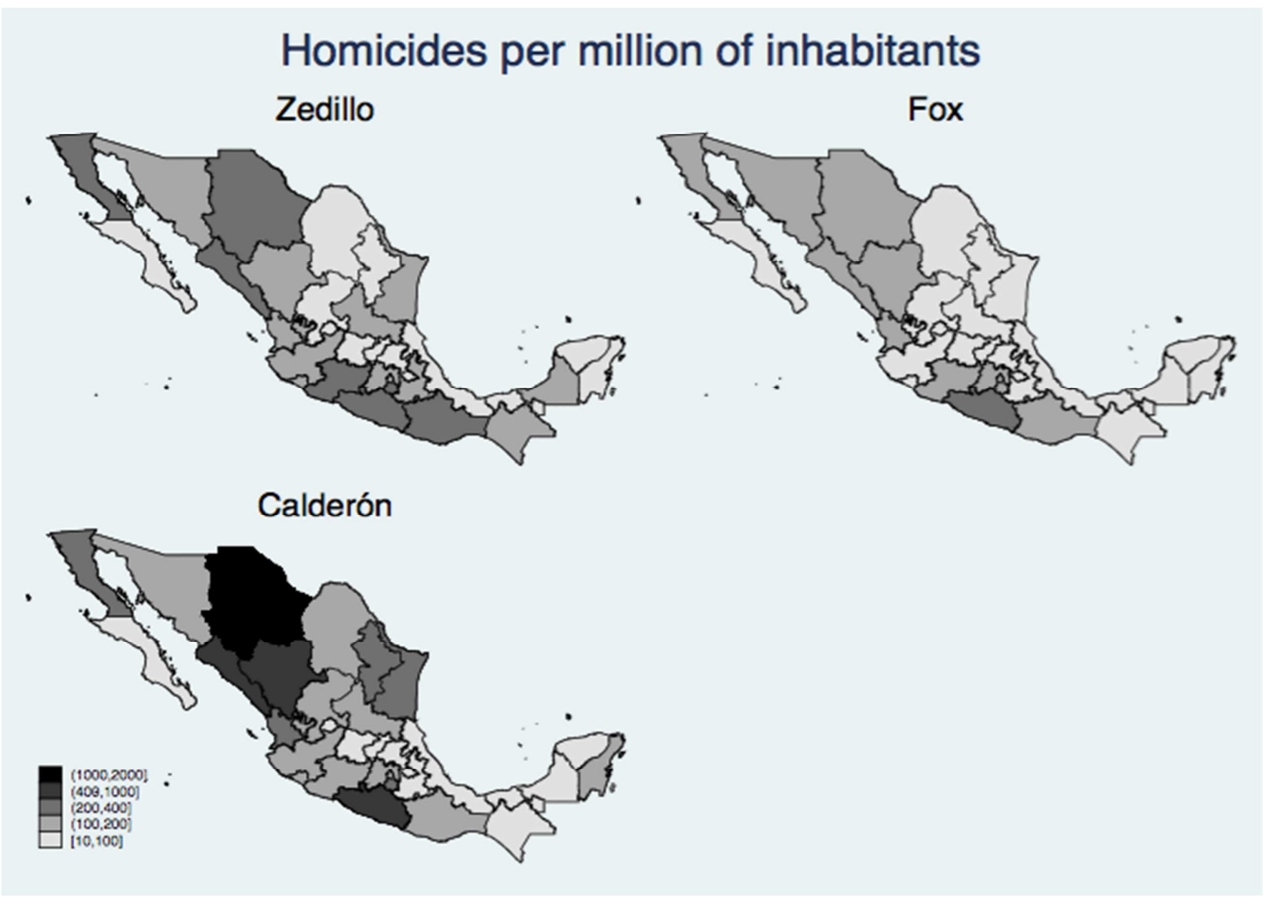

Source: made by the author using SHCP data

Map 1. Evolution of Violence in Mexico (1994-212).

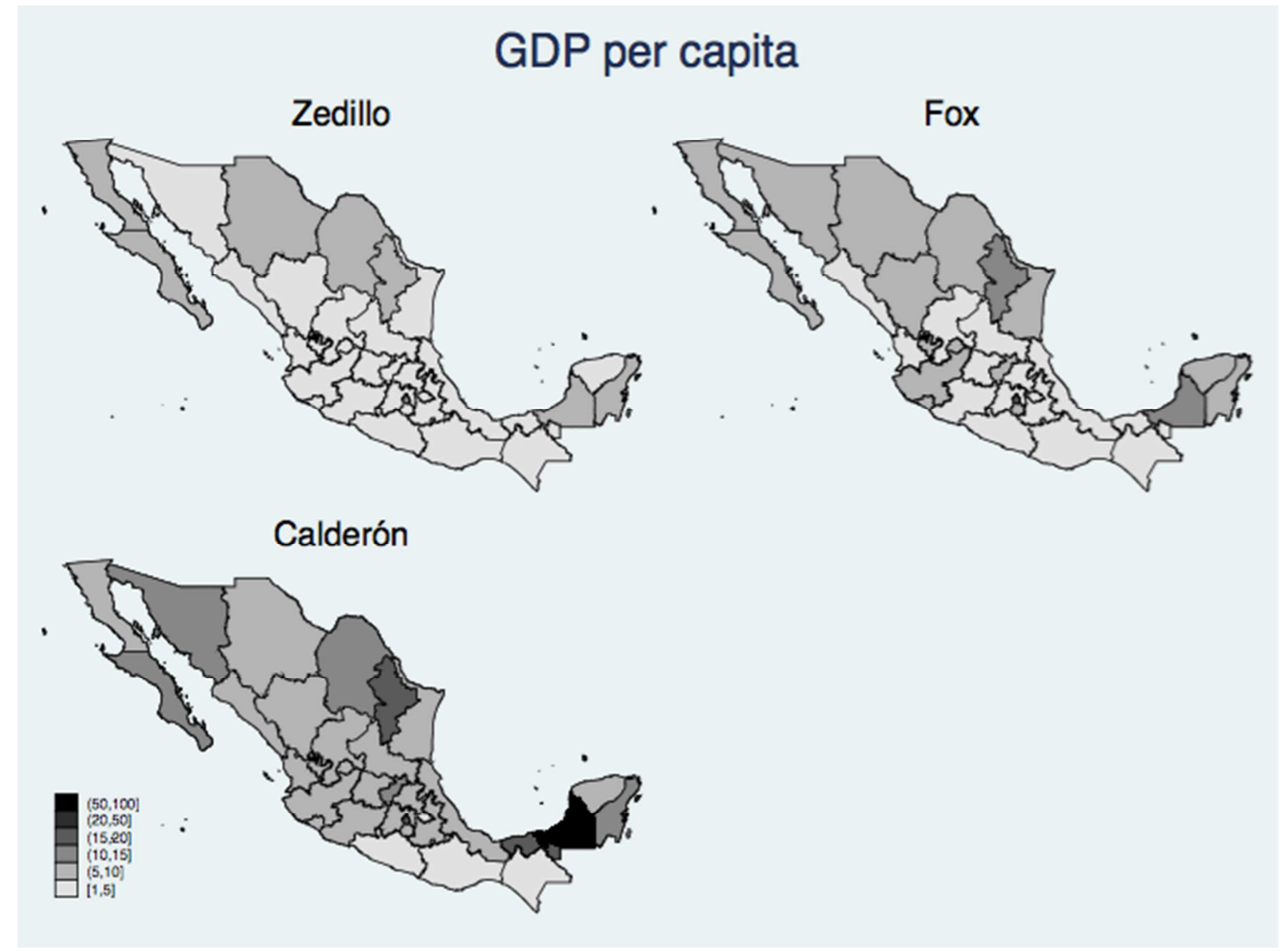

Source: made by the author using SHCP data

Map 2. Evolution of Wealth in Mexico. 


\section{Conclusions}

President FCH made the NSS one of the main pillars of his Administration. The NSS aimed at reestablishing law and order by fighting impunity and rebuilding social network. The NSS tackled criminality through three courses of action: a) contention, prosecution and weakening of criminal groups; b) strengthening and purification of justice and Public Security institutions and c) through the reconstruction of social network and campaigns to prevent delinquency. To finance the NSS, expenditure in Security doubled, going from 7.52 bn USD in 2006 to 14.95 bn USD in 2012 and its share in the Federal Budget as a whole increased from $4.56 \%$ in 2006 to $7.15 \%$ in 2012 . In comparison with EZP and VFQ, where more resources in security traduced in a contraction of homicides, by FCH for every 10,000 USD spent in Security, 5.8 homicides more were committed and for every criminal put in jail, homicides increased by 364 . The country as a whole turned even more violent by $\mathrm{FCH}$ in comparison with the former Presidential periods. Furthermore, during the presidency of EZL and VFQ, violence seemed to be inversely correlated with wealth in terms of GDP per head. However, there was not a strong evidence that that had been the case by $\mathrm{FCH}$, where wealth measured in terms of GDP per head, increased. Economic progress was concentrated in states like Nuevo León and Campeche, in which manufacturing and oil production experienced a boom. At the end, from 2006 to 2012, the country became more insecure and violent, but it turned more prosperous as well.

\section{Appendix}

Table A1. Results of the model 1

\begin{tabular}{|c|c|c|c|}
\hline $\mathbf{x}$ & Ln(GDP) Zedillo & Ln(GDP) Fox & Ln(GDP) Calderón \\
\hline Ln(Homicides) & $-0.751 * * *$ & $-0.083 *$ & 0.025 \\
\hline Aguascalientes & $-1.405 * * *$ & $-0.402 * * *$ & $-2.013^{* * *}$ \\
\hline Baja California & 0.147 & $-0.196 * *$ & $-2.075 * * *$ \\
\hline Baja California Sur & $-0.691 * * *$ & $-0.309 * * *$ & $-1.946 * * *$ \\
\hline Coahuila de Zaragoza & $-0.674 * * *$ & $-0.236^{* * *}$ & $-1.805^{* * *}$ \\
\hline Colima & $-0.629 * * *$ & $-0.536 * * *$ & $-2.107 * * *$ \\
\hline Chiapas & $-1.155^{* * *}$ & $-1.415 * * *$ & $-2.874 * * *$ \\
\hline Chihuahua & $0.228^{*}$ & -0.103 & $-2.110 * * *$ \\
\hline Distrito Federal & $0.469 * * *$ & $0.468 * * *$ & $-1.285^{* * *}$ \\
\hline Durango & $-0.510 * * *$ & $-0.606 * * *$ & $-2.243^{* * *}$ \\
\hline Guanajuato & $-1.454^{* * *}$ & $-0.870 * * *$ & $-2.283^{* * *}$ \\
\hline Guerrero & $-0.380 * *$ & $-1.024 * * *$ & $-2.803 * * *$ \\
\hline Hidalgo & $-1.616^{* * *}$ & $-1.152 * * *$ & $-2.425 * * *$ \\
\hline Jalisco & $-0.711 * * *$ & $-0.548 * * *$ & $-2.096^{* * *}$ \\
\hline México & $-0.429 * * *$ & $-0.802 * * *$ & $-2.445^{* * *}$ \\
\hline Michoacán de Ocampo & $-0.710 * * *$ & $-1.047 * * *$ & $-2.534 * * *$ \\
\hline Morelos & $-0.299 * *$ & $-0.616^{* * *}$ & $-2.424 * * *$ \\
\hline Nayarit & $-0.930 * * *$ & $-0.988 * * *$ & $-2.534 * * *$ \\
\hline Nuevo León & $-0.961 * * *$ & 0.008 & $-1.460 * * *$ \\
\hline Oaxaca & $-0.742 * * *$ & $-1.252 * * *$ & $-2.828^{* * *}$ \\
\hline Puebla & $-1.036^{* * *}$ & $-0.875 * * *$ & $-2.468 * * *$ \\
\hline Querétaro & $-0.747 * * *$ & $-0.405 * * *$ & $-1.885^{* * *}$ \\
\hline Quintana Roo & $-0.250^{*}$ & -0.068 & $-1.843^{* * *}$ \\
\hline San Luis Potosí & $-0.924 * * *$ & $-0.811 * * *$ & $-2.254 * * *$ \\
\hline Sinaloa & $-0.338 * *$ & $-0.728 * * *$ & $-2.260 * * *$ \\
\hline Sonora & $-0.294 * *$ & $-0.337 * * *$ & $-1.959 * * *$ \\
\hline Tabasco & $-1.249 * * *$ & $-0.975 * * *$ & $-1.446^{* * *}$ \\
\hline Tamaulipas & $-0.534 * * *$ & $-0.399 * * *$ & $-1.976^{* * *}$ \\
\hline Tlaxcala & $-1.567 * * *$ & $-1.181 * * *$ & $-2.699 * * *$ \\
\hline Veracruz de Ignacio de la Llave & $-1.392 * * *$ & $-1.066^{* * *}$ & $-2.393^{* * *}$ \\
\hline Yucatán & $-1.940 * * *$ & $-0.817 * * *$ & $-2.234 * * *$ \\
\hline Zacatecas & $-1.369^{* * *}$ & $-1.118 * * *$ & $-2.432 * * *$ \\
\hline Constant & $5.511 * * *$ & $2.698 * * *$ & $4.145^{* * *}$ \\
\hline $\mathrm{R}^{2}$ adjusted & 0.879 & 0.959 & 0.957 \\
\hline Obs. & 192 & 192 & 192 \\
\hline
\end{tabular}


Table A2. Results of model 1.

\begin{tabular}{|c|c|c|c|}
\hline & Ln(Homicides) Zedillo & Ln(Homicides)Fox & Ln(Homicides) Calderón \\
\hline Ln(GDP) & $-0.579 * * *$ & $-0.325^{*}$ & 0.475 \\
\hline Aguascalientes & $-1.591 * * *$ & $-1.029 * * *$ & 0.685 \\
\hline Baja California & $0.360 * * *$ & $0.909 * * *$ & $2.378^{* *}$ \\
\hline Baja California Sur & $-0.699 * * *$ & -0.138 & 0.862 \\
\hline Coahuila de Zaragoza & $-0.724 * * *$ & -0.185 & $1.499 *$ \\
\hline Colima & $-0.422 * * *$ & 0.162 & $1.794 *$ \\
\hline Chiapas & $-0.486^{* * *}$ & -0.187 & 1.081 \\
\hline Chihuahua & $0.461 * * *$ & $1.048^{* * *}$ & $3.442 * * *$ \\
\hline Distrito Federal & $0.339 * * *$ & $0.709 * * *$ & $1.117^{*}$ \\
\hline Durango & -0.14 & $0.446^{* *}$ & $2.815^{* * *}$ \\
\hline Guanajuato & $-1.228 * * *$ & $-0.602 * * *$ & 1.234 \\
\hline Guerrero & $0.373 * * *$ & $0.859 * * *$ & $3.229 * *$ \\
\hline Hidalgo & $-1.339 * * *$ & $-1.007 * * *$ & 0.768 \\
\hline Jalisco & $-0.521 * * *$ & -0.031 & $1.550^{*}$ \\
\hline México & 0.022 & $0.547^{* *}$ & $1.812 *$ \\
\hline Michoacán de Ocampo & -0.102 & $0.631^{* *}$ & $2.135^{*}$ \\
\hline Morelos & 0.132 & $0.328^{*}$ & $2.128^{*}$ \\
\hline Nayarit & $-0.412 * * *$ & $0.435^{*}$ & $2.459^{* *}$ \\
\hline Nuevo León & $-1.284 * * *$ & $-0.622 * * *$ & $1.444 *$ \\
\hline Oaxaca & 0.052 & $0.605^{* *}$ & $2.260^{*}$ \\
\hline Puebla & $-0.709 * * *$ & -0.155 & 1.129 \\
\hline Querétaro & $-0.726 * * *$ & $-0.296^{*}$ & 0.514 \\
\hline Quintana Roo & $-0.258^{* *}$ & $0.375 * * *$ & 1.359 \\
\hline San Luis Potosí & $-0.586^{* * *}$ & -0.162 & 1.494 \\
\hline Sinaloa & 0.174 & $0.798 * * *$ & $2.924 * * *$ \\
\hline Sonora & -0.125 & $0.436 * * *$ & $1.962^{* *}$ \\
\hline Tabasco & $-0.919 * * *$ & $-0.378^{*}$ & 0.866 \\
\hline Tamaulipas & $-0.356^{* * *}$ & 0.192 & $1.832 *$ \\
\hline Tlaxcala & $-1.204 * * *$ & $-0.641 * *$ & 1.055 \\
\hline Veracruz de Ignacio de la Llave & $-1.064 * * *$ & $-0.500^{*}$ & 1.273 \\
\hline Yucatán & $-1.973 * * *$ & $-1.221 * * *$ & -0.036 \\
\hline Zacatecas & $-0.964 * * *$ & -0.243 & 1.638 \\
\hline Constant & $5.899 * * *$ & $4.858^{* * *}$ & 2.197 \\
\hline R2 adjusted & 0.946 & 0.914 & 0.694 \\
\hline Obs. & 192 & 192 & 192 \\
\hline
\end{tabular}

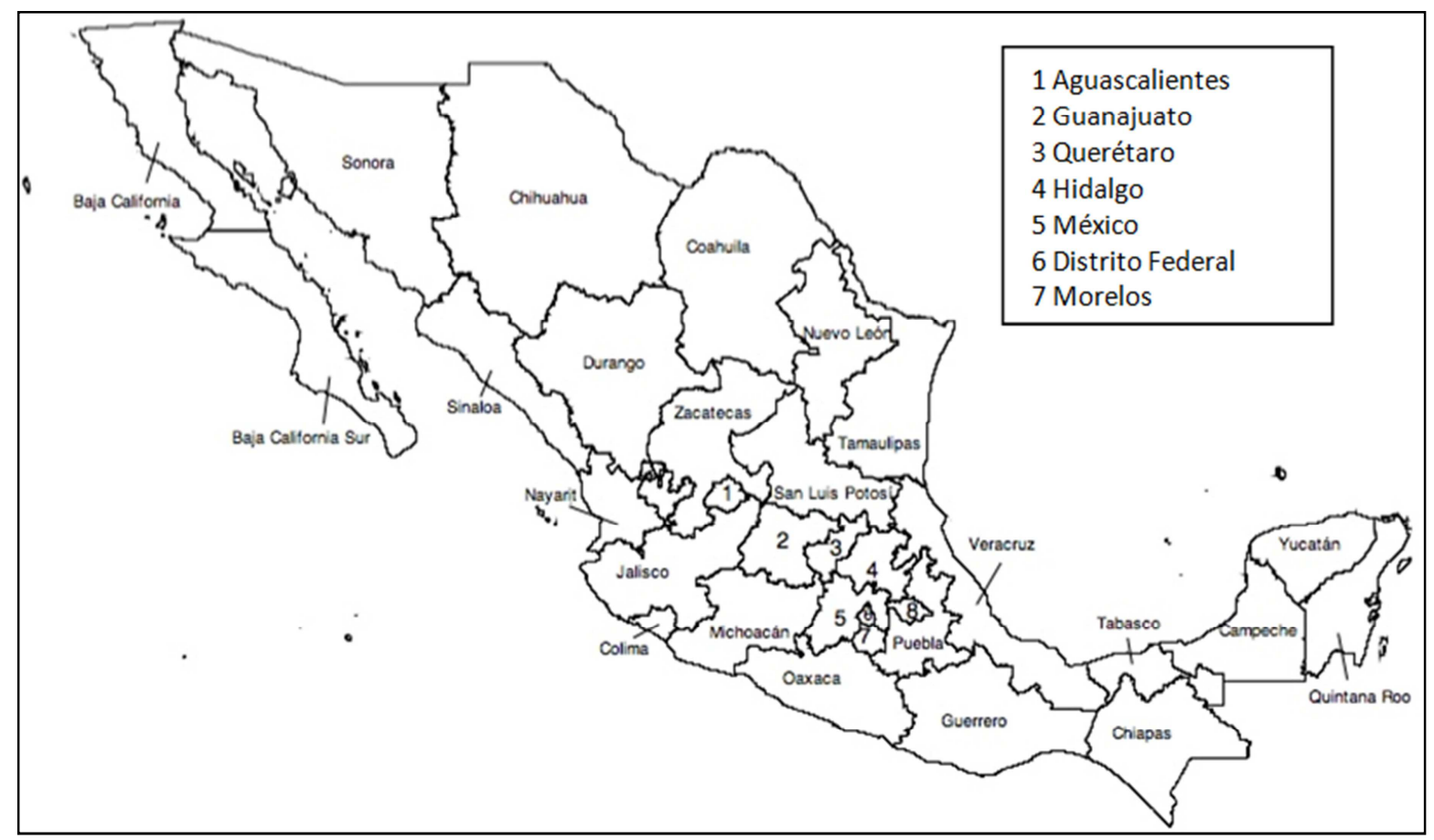

Map 3. Names of the Mexican Federal States. 


\section{References}

[1] Azaola, Elena (Mayo-junio, 2007). Las condiciones de vida en las cárceles mexicanas. Revista Mexicana de Ciencias Políticas y Sociales. Vol. XLIX, No. 200: 87-97.

[2] Astorga, Luis (2012). El siglo de las drogas. El narcotráfico, del porfiriato al nuevo milenio. México: Grijalbo.

[3] Bergman Marcelo y Elena Azaola (Mayo 2007). Cárceles en México. Cuadros de una crisis. Revista Latinoamericana de Seguridad Ciudadana. No. I, Quito: 74-87.

[4] Buscaglia, Edgardo (2013). Vacios de Poder en México. México: Debate.

[5] Calderón Hinojosa, Felipe (2014). Los retos que enfrentamos. Los problemas de México y las políticas públicas para resolverlos (2006-2012). México: Debate.

[6] Coss Nogueda, Magda (2011). Tráfico de armas en México. México: Grijalbo.

[7] Die Zeit. (2015). Gewehre für den Drogenkrieg. 18, Juni: 22.

[8] Dills, K Angela, Jeffrey A. Miron, Garret Summers (2008). What do economist know about crime. National Bureau of Economic Research. Working Paper 13759, January. http://www.nber.org/papers/w13759.

[9] El Universal (2012). Cronología de fugas masivas de reos en México. 7 de septiembre. http://www.eluniversal.com.mx/notas/870947.html Extraído en julio de 2014.

[10] Gasca Serrano, Leticia y Ricardo Aguilar (Octubre-Noviembre de 2012). Casas para presos. Expansión: 70-78.

[11] INEGI (2014). Mortalidad. Conjunto de Datos: defunciones por homicidios. http://www.inegi.org.mx/sistemas/olap/Proyectos/bd/continuas $/$ mortalidad/DefuncionesHom.asp?s=est\&c $=28820 \&$ proy $=$ mor t_dh Extraído en mayo de 2014.
[12] INEGI (2003). Encuesta Nacional de Victimización y Percepción sobre Seguridad Pública (ENVIPE). Tabulados básicos.

[13] Levitt, Steven y Stephen J. Dubner (2005). Freakonomics. New York: Harpen Collins Publishers.

[14] Paoli Bolio, Iván (2010). Evolución del Narcotráfico en México. Documentos de Trabajo 355. Fundación Preciado Hernández A. C.

[15] Poiré, Alejandro (Febrero de 2011). Los homicidios y la violencia del crimen organizado. Una revisión a la tendencia nacional. Nexos: 36-42

[16] Ravelo, Ricardo (2012). Osiel. México. Grijalbo.

[17] Reveles, José (2012). El Cartel incómodo. México. Grijalbo.

[18] SESNSP (2014). Incidencia Delictiva. Estadísticas y Herramientas de Análisis. Disponible en: http://www.estadisticadelictiva.secretariadoejecutivo.gob.mx/ mondrian/index_fc.htmlExtraído en mayo de 2014.

[19] Scherer García, Julio (2012). La reina del pacífico. México. Grijalbo.

[20] Sota, Alejandra y Miguel Messchasher (2012). Operativos y Violencia. $\quad$ Vol. $20 . \quad$ Nexos: http://www.nexos.com.mx/?p=15087 Extraído el 28 de junio de 2014.

[21] SHCP (2001-2012). Analíticos presupuestarios. Presupuesto de Egresos de la Federación. Análisis por unidad responsable (ramos).

[22] The Economist (2012). Mexico's Drug War. No so Fast. 21st January. http://www.economist.com/node/21543183.

[23] SSP (2008). Estrategia Penitenciaria 2008-2012. Subsecretaría del Sistema Penitenciario. Gobierno Federal. http://www.redlece.org/IMG/pdf/Manual_Estrategia_Penitenci aria_MX.pdf Extraído en enero 2014.

[24] Villalobos Joaquín (Enero de 2012). Nuevos mitos de la guerra contra el narco. Nexos: 28-41. 